\title{
FLORISTIC DIVERSITY OF MIDFOREST LAKES (SOBIBÓR LANDSCAPE PARK, POLAND)
}

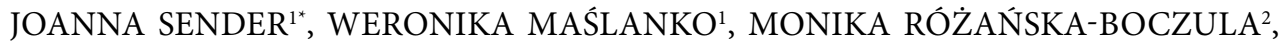 \\ MAGDA GARBOWSKI $^{3}$
}

${ }^{1}$ Department of Landscape Ecology and Nature Conservation, University of Life Sciences in Lublin, Dobrzańskiego 37 Street, 20-212 Lublin, Poland; e-mail: joanna.sender@up.lublin.pl

${ }^{2}$ Department of Applied Mathematics and Computer Science, University of Life Sciences in Lublin, Głęboka 28 Street, 20-950 Lublin, Poland

${ }^{3}$ Graduate Degree Program in Ecology, Colorado State University, 1177 Campus delivery, Fort Collins, CO 80523-1177

*Author for correspondence

\begin{abstract}
Sender J., Maślanko W., Różański-Boczula M., Garbowski M.: Floristic diversity of midforest lakes (Sobibór Landscape Park, Poland).Ekológia (Bratislava), Vol. 35, No. 4, p. 359-370, 2016.

Aquatic vegetation greatly impacts lake functions. Forest ecosystems surrounding lakes are effective protection zone of lakes and their associated flora and fauna. The presence of aquatic plants depends on many factors, including the chemical composition and acidity of water, the shape of the lake catchment, the angle of slope along shorelines and the management of surrounding lands. Natural ecosystems throughout Eastern Europe are threatened by anthropogenic activities. Aquatic systems and bogs are particularly sensitive to disturbances. The aim of the study was to determine the influence of land management, forest type and stand age on aquatic plant colonisation within lakes as well as to quantify and qualify the structure of macrophyte communities within two lakes, Płotycze Sobiborskie and Orchowe, located in the Sobibór Landscape Park in western Poland. Even though there were few bogs within the catchment areas and lake buffer zones, where they did occur they had the greatest effect on macrophyte presence. The results of this research indicate that in the absence of anthropogenic disturbances midforest water-bog complexes are relatively stable systems and preserve their natural character. The applied multi-criteria evaluation of macrophytes in the studied lakes and their surrounding buffer zones and catchment areas allowed the lakes to be characterised as lakes with a good ecological status.
\end{abstract}

Key words: macrophytes, polihumic lake, buffer zone, forest type.

\section{Introduction}

Mid-forest lakes, usually polihumic, belong to a group of habitats with specific environmental conditions. These are usually small reservoirs without outflow, storing a small volume of water. Primary production in lakes of this type is not high because of the low availability of mineral nutrients and a shallow euphotic zone. Only well-adapted aquatic plants and animals can handle these specific condition (Nürnberg, Shaw, 1999).

In shallow lakes with slightly acidic and clear water, aquatic vegetation may occupy large areas (Sender, 2008). The presence of aquatic plants depends on the chemical composition and acidity 
of water, the shape of the lake catchment, the angle of shoreline slope and the management of land in the catchment. Environment factors such as light, temperature, amount and availability of nutrients, sediment type, the angle of the substrate, hydrodynamic phenomena and human pressure effect macrophyte distribution (Sculthorpe, 1967; Szmeja, 2006, Jeppesen et al., 2012). In most polihumic dystrophic lakes, completely submerged macrophytes do not occur.

Aquatic vegetation at each stage of development has a great impact on the functioning of the whole lake. Most of fish inhabiting inland waters lay eggs on aquatic plants, and almost all require their presence to spawn (Bernatowicz, Wolny, 1974, Estlander et al., 2009). Thus, the presence of aquatic plants is essential for proper trophic structure of the reservoir. Their importance in aquatic biocenoses depends inter alia on plant species diversity, density of their population, littoral distribution and seasonality. As a result of anthropogenic activities, the current landscape is continuously changing and its natural features and components are being transformed and fragmented. These changes are caused by almost every kind of human activity, but the most intensive changes occur in urban and industrial areas. The expansion of human activity can lead to geomechanical transformation of terrain, vegetation cover and soil degradation and changes in the water cycle. Alterations in the hydrologic regime can lead to intensified surface runoff, decreases in subsurface infiltration and, most importantly, the introduction of polluted water and sewage waste into these ecosystems. Aquatic ecosystems including lakes are the primary reservoirs of these inputs. The quantity and quality of pollutants reaching these ecosystems depends largely on management in their catchments. As forest ecosystems are the most effective protection zone of lakes (Ebregt, Greve, 2000; Gamrat, Gałczyńska, 2014; Sławski, 2001), this study has been undertaken to determine the influence of catchment management and forest type on quantitative and qualitative structure of macrophytes in two lakes in eastern Poland. Forest type and catchment management may influence the presence and community structure of both emergent and floating leaved macrophytes.

\section{Material and methods}

Study site: Field studies were conducted during the growing season (spring, summer) in the years 2010 and 2011 in the lakes Płotycze Sobiborskie and Orchowe located in the eastern part of the Łęczna-Włodawa Lake District, within Sobibór Landscape Park (Fig. 1).

Typical of this area are forests covering 75\% of the Sobibór Landscape Park. The dominant species within the catchment are pine; however, homogeneous pine stands are absent. Coniferous forests are diverse in terms of community composition of tress and understory growth, as well as soil type and hydrologic regime. In areas with high soil moisture, dry coniferous stands, fresh coniferous, humid coniferous and bog coniferous occur. European White Birch and Alder Black dominated in forests were pine that constituted a small share of the forest stand. Deciduous broadleaved forests stands were not included in our study because larger patches are present only in the southern part of the park. Forests, peat bogs and wetlands surrounding lakes make them difficult to access. Polihumic, mid-forest lakes are often found in complexes with various priority habitats established by Natura 2000 : raised peat bogs with succession $(* 7110)$ and marshy coniferous forests $\left({ }^{\star} 91 \mathrm{D} 0\right)$. As dystrophic lakes are key components of larger hydrologic networks, protecting them is essential for protecting associated habitats.

Peat bogs are especially important to aquatic ecosystems because they slow and impede the flow of surface run off into lakes as well as reduce erosion. Peat bogs also improve water quality by aiding in the settlement of suspended materials and associated chemicals. Microfauna and microflora contribute on catching solutes and increase the amount of dissolved oxygen in water (Mioduszewski, 1995; Oleszczuk, Brandyk, 1997).

The research included a characterisation of land use type and forest type, in the catchment, buffer zone, and macrophyte characteristics in the littoral zone. The variability index for each zone was also calculated (Starzyńska, 2005). In addition, a qualitative analysis of macrophytes inhabiting lakes (area colonised by vegetation, species composition, extent 
of occurrence of individual formation) and quantitative analysis (total biomass of macrophytes by group and overall diversity) were completed. Biodiversity of each group of macrophytes was supported by the index of Shannon-Weaver (Hs) (Falińska, 2004).

To calculate the percent proportion of the different plant communities in lakes and their catchments, ArcGIS 10.0 software was used. Catchments of the studied lakes were determined using topographic maps at a scale of 1:25,000. Land use types structure analysis was done by a retrospective photointerpretative analysis (Chmielewski et al., 1996) using satellite scenes from the RapidEye satellite (5 spectral channels RGB+RE+NIR, 2009) as well as orthophotomap (2007). Satellite scenes were characterised by lower accuracy (1 pixel represented by $5 \mathrm{~m}$ in the field), but spectral channels allowed more precise distinction of different forms of land use types, such as wet meadows, agriculture agricultural fields or pastures and bogs. Orthophotomaps, though monochrome, were still the most ac-

curate available and had a terrain pixel size of $0.5 \mathrm{~m}$. Detailed analysis of land use types were carried out in lakes buffer zones, assuming the same radius length for lakes, $450 \mathrm{~m}$, measured from the centroid of lakes and set automatically by the ArcGIS software. The coordinates of centroid for Lake Orchowe, N 51 29' 26.92", E 23 34'21.91", and Lake Płotycze Sobiborskie, N 51 ${ }^{\circ} 23^{\prime} 38.27^{\prime \prime}$, E $23^{\circ} 37^{\prime} 0.01^{\prime \prime}$. Phytosociological study was performed by Braun-Blanquet method (1951). Phytosociological units were distinguished by using a systematic and nomenclature system of Matuszkiewicz (2008).

Counts of floating leaf and emergent macrophytes were collected along transects, five in Lake Płotycze Sobiborskie and four in Lake Orchowe (Jensen, 1977). The density of emergent vegetation and plants with floating leaves was determined using a floral fork. Analysis of emergent macrophytes included species composition, density (ind. per $\mathrm{m}^{2}$ ) and biomass of the species occurring in all research sites, as well as total biomass $\left(\mathrm{g}_{\mathrm{d}}\right.$ per $\left.\mathrm{m}^{2}\right)$, width and extent of rushes (m). Measurements of plants with floating leaves were conducted at $0.5-\mathrm{m}$ intervals from the shoreline to the maximum depth of their occurrence. Monitoring included analysis of species, total biomass $\left(g_{\mathrm{dm}}\right.$ per $\left.\mathrm{m}^{2}\right)$ and share of each species in biomass, as well as the extent of occurrence. Each measurement was repeated thrice (Sender, 2008).

Because the data were not normally distributed and not homogeneous according to Shapiro-Wilk and Fisher-Snedecor tests, a non-parametric test, Manna-Whitney U test, was used to determine the influence of macrophyte type on their biomass. To correctly discern the influence of measured variables on one another, a correspondence analysis was used. The spatial configuration of the results was interpreted according to Górniak (2000). We used this method to determine the influence of forest type and forest age on macrophyte species in the buffer zone. The correspondence analysis confirmed relationships between the investigated variables. All analyses were completed using Statistic 10.0.

\section{Results}

\section{Catchment analysis}

Catchment areas as well as studied lakes varied in size. Water surface of Lake Orchowe covered only 7.09 ha, and its catchments covered 429.3 ha. Lake Płotycze Sobiborskie was over two times 
larger, 15.8 ha, but the catchment area was only 170.3 ha. The length of the shoreline in Lake Płotycze S. (1926.2 m) was over $800 \mathrm{~m}$ longer than the shoreline of Lake Orchowe (1122.2 m).

Forests dominated both lakes' catchment areas, 94.1\% in Orchowe and 84.2\% in Płotycze S. Anthropogenic forms including agricultural fields, pastures, natural meadows and homesteads were present in the catchment area of Lake Płotycze Sobiborskie but absent from the catchment area of Lake Orchowe, where peat bogs were numerous (Table 1).

$\mathrm{T} \mathrm{a} \mathrm{b} \mathrm{l} \mathrm{e} \mathrm{1.} \mathrm{Forms} \mathrm{of} \mathrm{land} \mathrm{use} \mathrm{in} \mathrm{the} \mathrm{catchments} \mathrm{of} \mathrm{investigated} \mathrm{lakes.}$

\begin{tabular}{|c|c|c|c|c|}
\hline \multirow{2}{*}{ Land use forms in catchment } & \multicolumn{2}{|c|}{ Catchment of Lake Orchowe } & \multicolumn{2}{|c|}{$\begin{array}{c}\text { Catchment of Lake Płotycze } \\
\text { Sobiborskie }\end{array}$} \\
\hline & $\begin{array}{l}\text { Surface } \\
\text { [ha] }\end{array}$ & $\begin{array}{c}\text { Share in catchment } \\
{[\%]}\end{array}$ & $\begin{array}{l}\text { Surface } \\
\text { [ha] }\end{array}$ & $\begin{array}{c}\text { Share in catchment } \\
{[\%]}\end{array}$ \\
\hline Lake & 7.09 & 1.71 & 15.78 & 9.3 \\
\hline Transitional peat bog & 10.91 & 2.6 & 1.64 & 1.0 \\
\hline Raised peat bog with succession & 6.72 & 1.6 & 3.8 & 2.2 \\
\hline Dry coniferous forest & 26.05 & 6.4 & - & - \\
\hline Fresh coniferous forest & 293.21 & 72.4 & 41.14 & 29.4 \\
\hline Humid coniferous forest & 12.35 & 3.0 & 6.29 & 4.5 \\
\hline Marshy coniferous forest & 2.2 & 0.5 & 29.06 & 20.8 \\
\hline Fresh mixed coniferous forest & 8.75 & 2.2 & 39.51 & 28.4 \\
\hline Humid mixed coniferous forest & - & - & 12.05 & 8.7 \\
\hline Fresh mixed forest & - & - & 9.38 & 6.7 \\
\hline Humid mixed forest & 3.09 & 0.8 & 2.08 & 1.5 \\
\hline Marshy mixed forest & 56.60 & 14.1 & - & - \\
\hline Alder forest & 2.70 & 0.7 & - & - \\
\hline Meadows & - & - & 1.22 & 0.7 \\
\hline Meadows with succession & - & - & 0.91 & 0.5 \\
\hline Agricultural fields or pastures & - & - & 6.05 & 3.5 \\
\hline Homestead & - & - & 1.42 & 0.8 \\
\hline TOTAL & 429.7 & 100 & 170.3 & 100 \\
\hline
\end{tabular}

The catchment area covered with forests was larger at the Orchowe Lake (404.9 ha) as compared to the Płotycze S. lake (139.5 ha). At the Orchowe lake, fresh coniferous forest (FCF, 293.2 ha) dominated and marshy mixed forest (MmF, $56.6 \mathrm{ha}$ ) also covered a significant part of the area. Fresh stand $(\mathrm{FmF})$ or humid mixed coniferous forests $(\mathrm{HmCF})$ were not observed at this location. The forest types at Lake Płotycze S. were varied but FCF, marshy coniferous forest (MCF) and fresh mixed coniferous forest (FmCF) dominated (reaching, respectively, 41.1, 29.1 and 39.5 ha coverage of catchment area). Alder forest (AF), marshy mixed forest (MmF) and dry coniferous forest (DCF) were not observed in the catchment area of Płotycze S. lake (Table 1).

The age structure of tree stands in individual catchments varied. In both lakes, Lake Orchowe and Lake Płotycze, middle-aged trees contributed to the smallest share of area at $32 \%$ and $29 \%$, respectively. Old trees comprised the largest share of the areas, covering $42 \%$ and $46 \%$ of the areas at Lake Orchowe and Lake Płotycze, respectively, and young trees covered similar areas at 27\% and $25 \%$, respectively (Fig. 2). 
The greatest portion of the catchment areas in Lake Orchowe was occupied by FCF. Furthermore, FCF habitat type has the highest differentiation of stand age with the youngest trees dominating (Age 1). In addition, $\mathrm{MmF}$ habitat type was also differentiated by age; however, within this habitat type, the oldest trees dominate. The remaining habitat types were not greatly differentiated by forest stand age (Fig. 3).

Within the catchment area of Lake Płotycze Sobiborskie, forest stand was very diverse based on tree age. The greatest area was occupied by older trees (Age 3) of forest types: FCF, MCF and FmCF. The youngest stands included FCF, MCF, HmCF, FmF and HmF (Fig. 4).

\section{Buffer zone analysis}

The primary land use type in the area directly adjacent to the shoreline of Lake Orchowe were transition peat bogs and raised peat bog with succession. However, in the buffer zone $(450 \mathrm{~m}$ from shoreline) of Lake Płotycze S., in addition to transitional peat bogs, MCF were present and occupied more than $20 \%$ of its length. The buffer zone, also known as the transit zone, can be managed to reduce the negative anthropogenic impacts. As the diversity of habitats and species in this zone increase, so does the value of the habitat as a biofilter (Ebregt, Greve, 2000). Forests dominated the buffer zones of the studied lakes; FCF on Lake Orchowe and DCF and MCF on Lake Płotycze Sobiborskie occurred (Table 2).

The variability index varied amongst the buffer zone and catchment in lakes. The value of the index for the catchment was $106 \%$ in Lake Płotycze S. and $49 \%$ in Lake Orchowe. The variability index for the buffer zone of Lake Płotycze S., 171\%, was significantly higher than that of

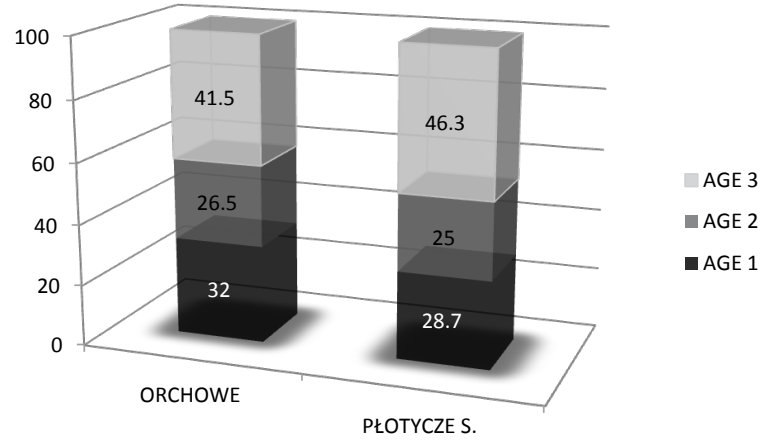

Fig. 2. Stand age diversity in catchments of investigated lakes (Age $1,<30$ years; Age 2, between 30 and 60 years; Age 3, > 60 years).

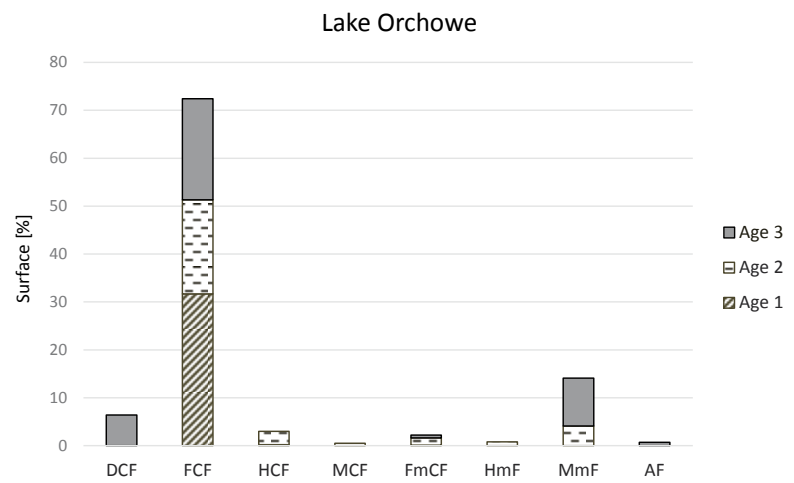

Fig. 3. Age differentiation within each forest habitat type at Lake Orchowe. AF, alder forest; $\mathrm{MmF}$, marshy mixed forest; HmF, humid mixed forest; FmCF, fresh mixed coniferous forest; MCF, marshy coniferous forest; HCF, humid coniferous forest; FCF, fresh coniferous forest; DCF, dry coniferous forest. 


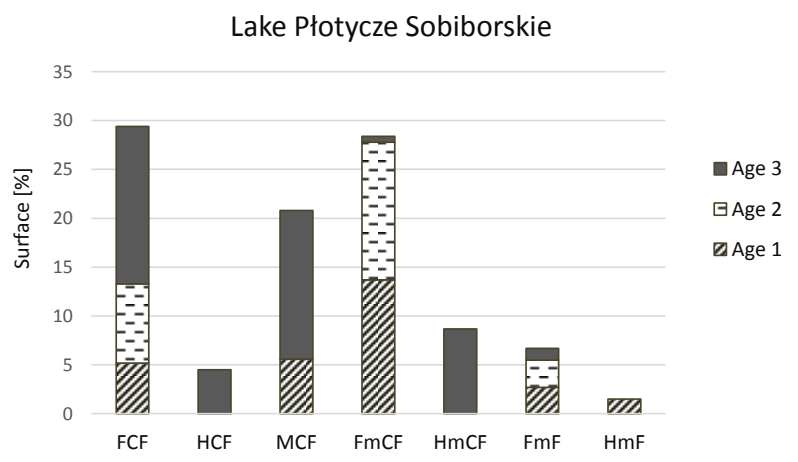

Fig. 4. Diversification of the forest stands by stand age within the catchment area of Lake Płotycze Sobiborskie. HmF, humid mixed forest; FmF, fresh mixed forest; HmCF, humid mixed coniferous forest; FmCF, fresh mixed coniferous forest; MCF, marshy coniferous forest; HCF, humid coniferous forest; FCF. fresh coniferous forest.

the Lake Orchowe, $82 \%$. Our interactions with macrophytes were based on buffer zone.

\section{Macrophyte analysis}

Macrophytes occupied a small area in the studied lakes. In the Lake Płotycze S., macrophytes covered 3.25 ha of the lake, and in Lake Orchowe, 2.27 ha, approximately $20.6 \%$ and $32 \%$ (Table 4) of lake surface area, respectively. The phytolittoral zone was definitely dominated by emergent macrophytes (Table 3), just as in other mid-forest lakes in the Łęczyńsko-Włodawskie Lakeland region (Sender, 2009).

In both lakes, no submerged plants were found but both emergent macrophytes and floatingleaved macrophytes were present. Four communities of emergent macrophytes were present. The largest share of these communities were reeds, particularly Phragmitetum australis, and amongst the plants with floating leaves, Nupharo-Nymphaeetum albae community (Table 3).

The deepest macrophytes occurred in Lake Płotycze S. and were found at a depth of up to 1.5 $\mathrm{m}$ (Table 4). Colonisation of individual depth by aquatic plant is closely connected with visibility, as evidenced by the high value of the correlation coefficient $-0.94(\mathrm{p}=0.05)$.

$\mathrm{T}$ a b l e 2. Land use forms in buffer zones of investigated lakes.

\begin{tabular}{|c|c|c|c|c|}
\hline \multirow[b]{2}{*}{ Land use forms in buffer zones } & \multicolumn{2}{|c|}{ Lake Orchowe } & \multicolumn{2}{|c|}{ Lake Płotycze Sobiborskie } \\
\hline & Surface [ha] & $\begin{array}{c}\text { Share in buffer } \\
\text { zone [\%] }\end{array}$ & Surface [ha] & $\begin{array}{c}\text { Share in buffer } \\
\text { zone [\%] }\end{array}$ \\
\hline Lake & 7.09 & 11.1 & 15.78 & 24.8 \\
\hline Transitional peat bog & 2.89 & 4.5 & 1.64 & 2.6 \\
\hline Raised peat bog with succession & 4.32 & 6.8 & 3.12 & 4.9 \\
\hline Dry coniferous forest & 14.73 & 23.1 & - & - \\
\hline Fresh coniferous forest & 21.86 & 34.4 & 17.21 & 27.1 \\
\hline Humid coniferous forest & 4.43 & 7.0 & 3.7 & 5.8 \\
\hline Marshy coniferous forest & - & - & 14.27 & 22.4 \\
\hline Fresh mixed coniferous forest & - & - & 1.36 & 2.1 \\
\hline Humid mixed coniferous forest & - & - & 6.35 & 10.0 \\
\hline Humid mixed forest & 2.43 & 3.8 & - & - \\
\hline Marshy mixed forest & 5.84 & 9.2 & - & - \\
\hline Field & & & 0.16 & 0.25 \\
\hline Variability index \% (catchment) & \multicolumn{2}{|c|}{49} & \multicolumn{2}{|c|}{106} \\
\hline Variability index \% (buffer zone) & \multicolumn{2}{|c|}{82} & \multicolumn{2}{|c|}{171} \\
\hline Total & 63.6 & 100 & 63.6 & 100 \\
\hline
\end{tabular}


Significant differences in macrophyte biomass were found between the macrophyte types, emergent and floating leaved ( $\mathrm{p}<0.0001$ ), in both lakes. Emergent macrophytes had over two times greater biomass than macrophytes with floating leaves (Fig. 5). In Lake Orchowe, emergent macrophytes reached biomass values of $626.3 \mathrm{~g}_{\mathrm{dw}} \cdot \mathrm{m}^{-2}$, but values were much lower for floatingleaved macrophytes $-71.6 \mathrm{~g}_{\mathrm{dw}} \cdot \mathrm{m}^{-2}$. In Lake Płotycze S., emergent macrophyte biomass was 298.6 and $47.4 \mathrm{~g}_{\mathrm{dw}} \cdot \mathrm{m}^{-2}$ for others plants.

In buffer zone of Lake Płotycze S., macrophytes were densest in the vicinity of humid forest and sparsest in areas adjacent to marshy forest and transition peat bogs. The density of Phragmites australis was great in areas where DCF, HCF and HmCF forests were present. In areas were DCF and HCF were present, Scirpus lacustris, Typha angustifolia and Nymphaea alba were common, but emergent macrophytes dominated overall. Floating-leaved macrophytes appeared intermittently in the vicinity of $\mathrm{HmCF}$ at Lake Płotycze S. In zones where MCF and transitional peat bog (TP) were present, there was little differentiation and occurrence of either emergent or floatingleaved macrophytes (Fig. 6).

$\mathrm{T}$ a b l e 3. Surface area of particular plant communities in studied lakes.

\begin{tabular}{|l|c|c|}
\hline Plant communities & Lake Płotycze Sobiborskie & Lake Orchowe \\
\hline Potametum natantis Soo 1927 & 8.7 & 2.2 \\
\hline Nupharo-Nymphaeetum albae Tomasz. 1977 & 9.4 & 4.2 \\
\hline Nymphaeetum candidae Miljan 1958 & 3.8 & - \\
\hline Eleocharitetum palustris Šennikov 1919 & 0.4 & 0.5 \\
\hline Phragmitetum australis (Gams 1927) Schmale 1939 & 35 & 15.9 \\
\hline Typhetum angustifoliae (Allorge 1922) Soo 1927 & 23 & 8.4 \\
\hline Typhetum latifoliae Soo 1927 & - & - \\
\hline Scirpetum lacustris (Allorge 1922) Chouard 1924 & 4.8 & 3.6 \\
\hline Equisetetum fluviatilis Steffen 1931 & - & - \\
\hline Caricetum vesicariae Br-Bl. et Denis 1926 & 0.8 & - \\
\hline Caricetum paniculatae Wangerin 1916 & 0.5 & 1.5 \\
\hline Caricetum elatae 1926 & 2.3 & 0.9 \\
\hline Thelypteridi-Phragmitetum Kuiper 1957 & - & 0.6 \\
\hline Caricetum acutiformis Sauer 1937 & 1.9 & - \\
\hline Cicuto-Caricetum pseudocyperi Boer et Siss. in Boer 1942 & 1.3 & - \\
\hline Scorpidio-Utricularietum minoris Müll. et Grös 1960 & 8.1 & 10 \\
\hline Total number & 13 & \\
\hline
\end{tabular}

T a b l e 4. Characteristics of phytolittoral in investigated lakes.

\begin{tabular}{|c|c|c|c|c|c|c|c|c|}
\hline \multirow{2}{*}{ Lake } & \multicolumn{2}{|c|}{ Depth (m) } & \multirow{2}{*}{$\begin{array}{l}\text { Colonisation } \\
\text { depth }(\mathbf{m})\end{array}$} & \multirow{2}{*}{$\begin{array}{l}\text { SD visibility } \\
\text { (m) }\end{array}$} & \multicolumn{2}{|c|}{$\begin{array}{c}\text { Total area } \\
\text { of phytolittoral }\end{array}$} & \multicolumn{2}{|c|}{ Phytolittoral surface (ha) } \\
\hline & Max & Mean. & & & ha & $\%$ & $\begin{array}{c}\text { Emergent } \\
\text { (ha) }\end{array}$ & $\begin{array}{c}\text { Plants with float- } \\
\text { ing leaves (ha) }\end{array}$ \\
\hline Płotycze S. & 7.8 & 2.2 & 1.5 & 1.2 & 3.25 & 20.6 & 2.1 & 1.15 \\
\hline Orchowe & b.d. & b.d. & 1.1 & 0.55 & 2.27 & 32 & 1.97 & 0.3 \\
\hline
\end{tabular}




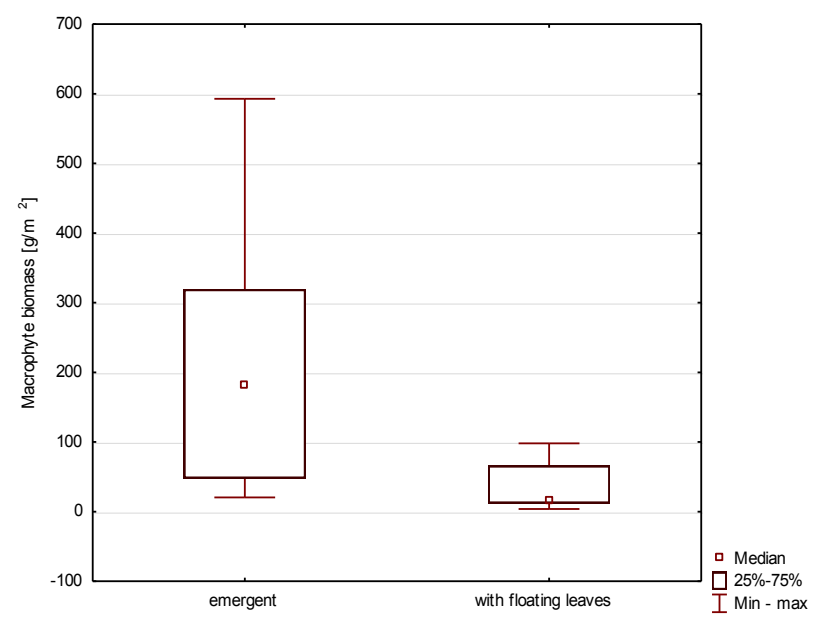

Fig. 5. Macrophyte biomass for two groups, emergent and floating leaves.

The largest species diversity and density of macrophytes in Lake Orchowe occurred in the vicinity of humid mixed forest (HmF) (Fig. 7). Six species occurred in this area and Phragmites australis reached the highest densities. At this lake, the lowest values of density and species number were reached in areas where macrophytes grew adjacent to raised peat bogs with succession (Hs). There were only two species with low biomass (Fig. 7).

Floating-leaved macrophyte species were more numerous in the Lake Orchowe than in Lake

Płotycze S. The greatest difference in macrophyte diversity was found in areas with $\mathrm{HmF}$ and TP. The density of $P$. australis density was highest in DCF, HmF and Hs areas, but the density of Typha angustifolia was also very high in DCF. Carex elata had the greatest density in transects from TP areas.

In both the mid-forest lake buffer zones, specific macrophytes dominated based on biomass in different habitat types (Fig. 8).

1. Carex vesicaria, Typha angustifolia and Scirpus lacustris reached the greatest biomass in transects with FCF and HCF.

2. Phragmites australis, Potamogeton natans, Nymphaea alba and Utricularia intermedia were highest in transects: MCF, HmCF and high moor with succession (Hs).

3. Nuphar lutea and Typha latifoliae had the highest biomass in transects from the HmF habitat.

4. Carex elata, Eleocharis palustris and Scorpidium scorpioides had the highest biomass cover in transects from the TPTP habitats.

Scirpus lacustris occurred most often in the vicinity of young forest, whilst Typha latifoliae and Nuphar lutea occurred most often in the vicinity of middle-age trees. The greatest diversity of macrophyte species was found associated with the oldest forests, with trees over 60 years (Fig. 9).

The Schannon-Weaver diversity index value, defined only for macrophytes, for Lake Orchowe is 1.4 and for the Lake Płotycze S. is 1.8. The importance of such lakes as valuable natural features is confirmed by the presence of rare and endanger plants, including Nymphaea candida, Nuphar lutea, Scorpidium scorpioides, Utricularia minor and U. intermedia (Zarzycki, 2006).

\section{Discussion}

Small, mid-forest, impassable humotrophic lakes together with transitional and raised peat bog dominated by the communities of Scheuchzerio Caricetea and Oxycocco-Sphagnetea have low 


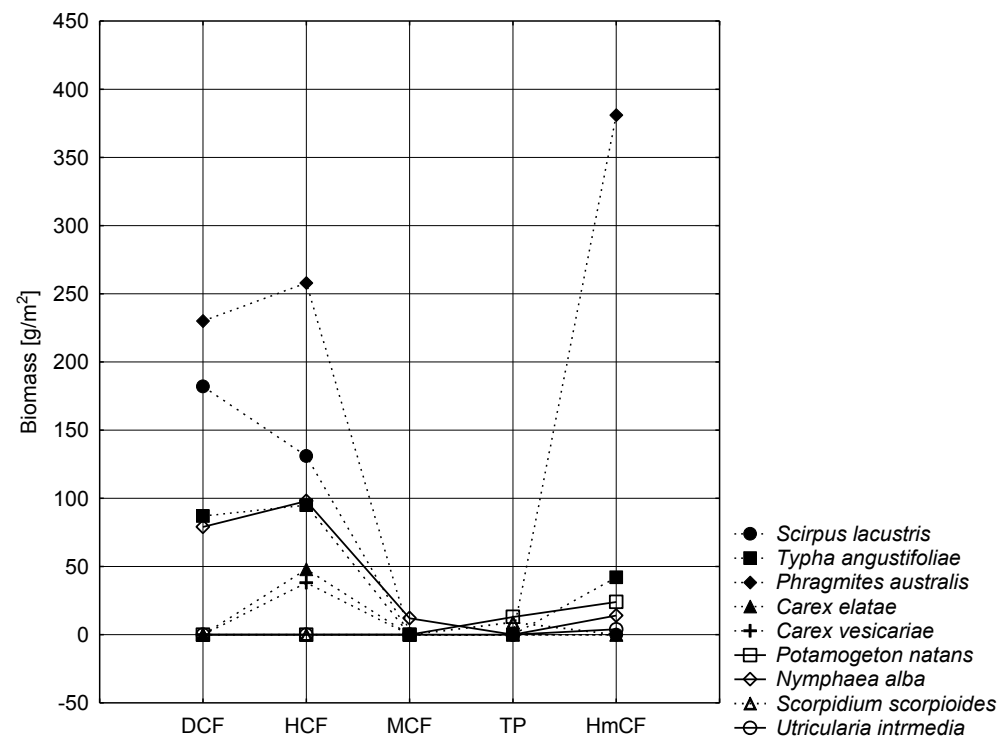

Fig. 6. Diversification of macrophyte density (dashed line, emergent; solid line, floating leaf macrophytes) by forest type in buffer zone of Lake Płotycze S. TP, transitional peat bog; HCF, humid coniferous forest; MCF, marshy coniferous forest; HmCF, humid mixed coniferous forest; DCF, dry coniferous forest.

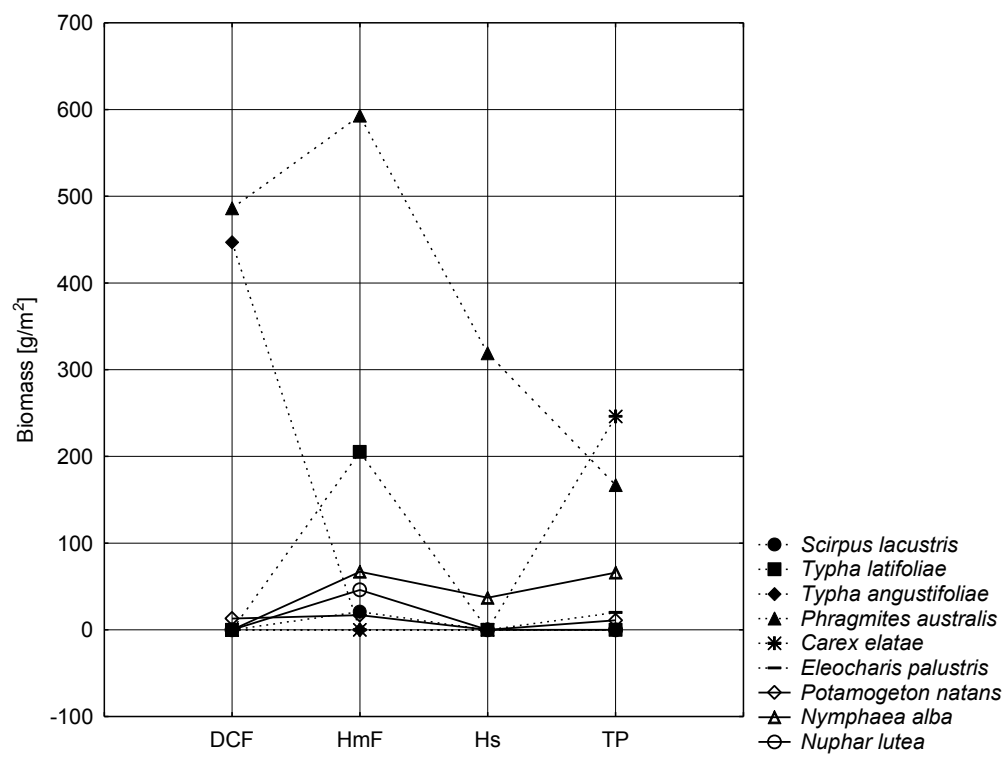

Fig. 7. Diversification of macrophyte density (dashed line, emergent; solid line, floating-leaved macrophytes) by forest type in buffer zone of Lake Orchowe. TP, transitional peat bog; Hs, raised peat bog with succession; HmF, humid mixed forest; DCF, dry coniferous forest. 


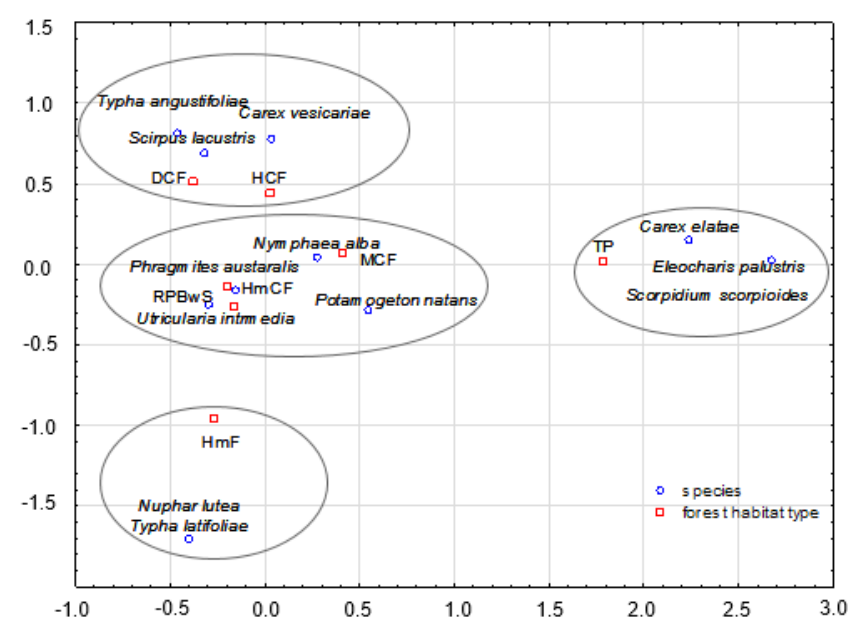

Fig. 8. Correspondent analysis (inertia analysis) between species biomass and forest habitat type in buffer zone of investigated lakes. Total inertia is 0.99 . Two dimensions explained a total of $77 \%$ of inertia (axis $1-45.04 \%$, eigenvalue: 0.45 ; axis $2-32.07 \%$, eigenvalue: 0.32 ).

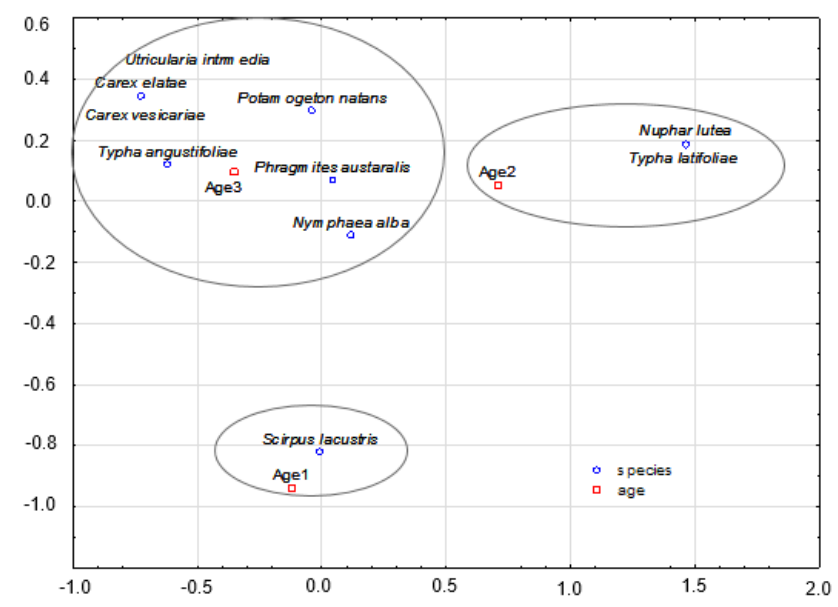

Fig. 9. Correspondent analysis (inertia analysis) between species biomass and forest age type in buffer zone of investigated lakes. Total inertia is 0.31 . Two dimensions explained a total of $100 \%$ of inertia (axis $1-75.79 \%$, eigenvalue: 0.24 ; axis $2-24.21 \%$, eigenvalue: 0.08 ). abundance of nutrients but high content of humic substances (Eloranta, 1999). These high humic substances give a characteristic brownish-yellow colour to the water, which restricts access of light and limits the development of submerged macrophytes (Górniak, 1996; Mäkelä et al., 2004). Subsequently, the lack of submerged plants limits the use of standardised botanical indicators such as Ecological State Macrophyte Index to evaluate the ecological status of lakes (Chylińska, 2015). There are no typical indicators to determine the ecological status of polihumic lakes based on all types of macrophytes. Rather, submerged macrophytes are often used as indicators of ecological status (Coops et al., 2007; Penning et al., 2008; Søndergaard et al., 2010). Polihumic lakes are generally depauperate of aquatic vegetation (Kufel et al., 2004). Indexes to qualify the ecological states are unavailable for these types of lakes. Emergent macrophytes dominate these types of lakes and only recently have been included as indicators for the ecological state

of lakes (Alahuhta et al., 2013; Kolada, 2016). According to Muskoka (2013) and Alahuhta et al. (2013), land use adjacent to shoreline had a higher effect on emergent macrophytes compared to the whole catchment (Muskoka, 2013; Alahuhta et al., 2013). Our results indicate that some forest types and forest age influence the types of macrophytes present. In areas adjacent to the oldest 
forest stands, macrophyte diversity and biomass were high. Four groups of emergent macrophytes were distinguished based on forest type.

According to the Shannon-Weaver diversity index, the lakes monitored in this study were found to be floristically valuable. This is supported by specific species found in these sorts of lakes: Scorpidium scorpioides, Utricularia spp., Nymphaea candida, Nuphar lutea, Potamogeton natans et al., for dystrophic lakes (3160).

Despite great similarities in catchment management, Orchowe Lake had a larger phytolittoral surface area and overall macrophyte biomass was greater. In this lake catchment, an FCF with relatively young trees dominated, whereas a bog dominated the area immediately adjacent to the shoreline. In the Płotycze Sobiborskie lake, the habitats present within the catchment were mixed; however, the greatest proportion of area was covered with bog forest and fresh mixed forest, both were dominated by old trees. In the Płotycze Sobiborskie lake, macrophytes inhabited a much smaller area, but species diversity was significantly higher than that in the Orchowe lake. Macrophytes reached higher values for cover and biomass at both locations were young tree stands were present within the catchment area.

humotrophic mid-forest lakes along with associated peat bog communities retain water and slow runoff. In general, because of the absence of human impact, mid-forest water and bogs complexes are relatively stable systems and retain their natural character. Specific hydrogeological factors caused that the greatest threat to these valuable, mid-forest habitats are drainage systems, as well as reduction of groundwater level in the catchment (Namura-Ochalska, 2008). In the studied lakes, macrophytes were sparse were peat bogs present,. The buffer zone, also known as the transit zone, can be managed to reduce the negative anthropogenic impacts. The greater the diversity of habitats and species of this zone, the higher is its value as a biofilter (Ebregt, Greve, 2000; Dudley, Stolton, 2003). Forests dominated the buffer zones of the studied lakes.

\section{Conclusion}

There are no specific indexes to assess the ecological state of rare ecosystems of mid-forest lakes. The environmental conditions present in these systems limit the occurrence of aquatic plants to emergent and floating-leaved plants. Our results suggest that forest age and the management of the buffer zones areas greatly influence the macrophyte communities.

\section{References}

Alahuhta, J., Kanninen, A., Hellsten, S., Vuori, K., Kuoppala, M. \& Hämäläinen H. (2014). Variable response of functional macrophyte groups to lake characteristics, land use, and space: implications for bioassessment. Hydrobiologia, 737(1), 201-214. DOI: 10.1007/s10750-013-1722-3.

Bernatowicz, S. \& Wolny P. (1974). Botany for limnologists and fishermen (in Polish). Warsaw: PWRiL.

Braun-Blanquet, J. (1951). Pflanzensoziologie. Wien: Springer Erlang.

Chmielewski, T.J., Olenderek, H. \& Sielewicz B. (1996). Retrospective analysis of changes in ecological structure Kampinos National Park in the last 40-year period (in Polish). In M. Kistowski (Ed.), Badania ekologiczno-krajobrazowe na obszarach chronionych (pp. 125-129). Gdańsk: Uniwersytet Gdański, Polska Asocjacja Ekologii Krajobrazu.

Chilińska, E. (2015). Ecological status assessment of lakes using macrophytes. Folia Biologica et Oecologica, 11, 16-22. DOI: $10.1515 /$ fobio-2015-0003.

Coops, H., Kerkum, F.C.M., van den Berg, M.S. \& van Splunder I. (2007). Submerged macrophyte vegetation and the European Water Framework Directive: assessment of status and trends in shallow, alkaline lakes in the Netherlands. 
Hydrobiologia, 584, 395-402. DOI: 10.1007/s10750-007-0586-9.

Dudley, N. \& Stolton S. (2003). The importance of forest protected areas to drinking water. A research report for World Bank WWF Alliance for Forest Conservation and Sustainable Use. UK.

Ebregt, A. \& Greve P.D. (2000). Buffer zones and their management: policy and best practices for terrestrial ecosystems in developing countries. Wageningen: National Reference for Nature Management; International Agricultural Centre.

Eloranta, P. (1999). Humic matter and water colour. In J. Keskitalo, P. Eloranta (Eds.), Limnology of humicwaters (pp. 61-74). Leiden: Backhuys Publisher.

Estlander, S., Nurminen, L., Olin, M., Vinni, M. \& Horppila J. (2009). Seasonal fluctuation in macrophytecover and water transparency of four brown-water lakes: implications for crustacean zooplankton in littoral and pelagic habitats. $H y-$ drobiologia, 620, 109-120. DOI: 10.1007/s10750-008-9621-8.

Falińska, K. (2004). Plant ecology (in Poland). Warsaw: PWN.

Gamrat, R. \& Gałczyńska M. (2014). Influence of the ecotone zone of forest on phyto-diversity (in Polish). Sylwan, 158(1), 34-40.

Górniak, A. (1996). Humic substances and their role in functioning of freshwater ecosystems (in Polish). Dissertationes Universitatis Varsoviensis, Bialystok.

Górniak, J. (2000). The use of correspondence analysis in social research and marketing (in Polish). ASK, 9, 115-134.

Jensen, S. (1977). An objective method for sampling the macrophyte vegetation in lakes. Vegetatio, 33(2/3), 107-118. http://www.jstor.org/stable/20036970

Jeppesen, E., Søndergaard, M., Søndergaard, M. \& Christoffersen K. (2012). The structuring role of submerged macrophytes in lakes. Springer Science \& Business Media.

Kolada, A. (2016). The use of helophytes in assessing eutrophication of temperate low land lakes: Added value?. Aquat. Bot., 129, 44-54. DOI: 10.1016/j.aquabot.2015.12.002.

Kufel, L., Kufel, I. \& Królikowska J. (2004). The effect of lake water characteristics on decomposition of aquatic macrophytes. Pol. J. Ecol., 52(3), 261-273.

Mäkelä, S., Huitu E. \& Arvola L. (2004). Spatial patterns in aquatic vegetation composition and environmental covariates along chains of lakes in the Kokemäenjoki watershed (S. Finland). Aquat. Bot., 80, 253-269. DOI: 10.1016/j. aquabot.2004.08.006.

Matuszkiewicz, W. (2008). Guide for the determination of plant communities in Polish (in Polish). Warsaw: PWN.

Mioduszewski, W. (1995). The role of peatlands in the development of water resources of small river basins. Peatlands in research and practice (in Polish). Materialy Seminaryjne IMUZ, 34, 305-314.

Muskoka Watershed Council (January 2013). Shoreline vegetative buffers. www.muskokawatershed.org

Namura-Ochalska, A. (2008). Mid-forest lakes oligo-humotrophic, as natural reservoirs (in Polish). In D. Anderwald (Ed.), Woda dla lasu, las dla wody (pp. 125-139). Studia i Materiały Centrum Edukacji Przyrodniczo-Lésnej, 10, 2(18).

Nürnberg, G.K. \& Shaw M. (1999). Productivity of clear and humic lakes: nutrients, phytoplankton, bacteria. Hydrobiologia, 382, 97-112. DOI: 10.1023/A:1003445406964.

Oleszczuk, R. \& Brandyk, T. (1997). Selected problems of conservation of peat soils (in Polish). Warsaw: Wydział Melioracji i Inżynierii Środowiska SGGW.

Penning, W.E., Dudley, B., Mjelde, M., Hellsten, S., Hanganu, J., Kolada, A., van den Berg, M., Poikane, S., Phillips, G., Willby, N. \& Ecke F. (2008). Using aquatic macrophyte community indices to define the ecological status of European lakes. Aquat. Ecol., 42, 253-264. DOI: 10.1007/s10452-008-9183-x.

Sculthorpe, C.D. (1967). The biology of aquatic vascular plants. Reprint 1985. Konigstein: Koeltz Scient. Books.

Sender, J. (2008). Long term changes of macrophytes structure in the Lake Moszne (Poleski National Park). TEKA Komisji Ochrony i Kształtowania Środowiska Przyrodniczego, 5, 154-163.

Sender, J. (2009). Changes occurring in water phytocenoses and flora of macrophytes studied lakes 1960-2009 (in Polish). In T.J. Chmielewski (Ed.), Ekologia krajobrazów hydrogenicznych Rezerwatu Biosfery „Polesie Zachodnie” (pp. 161-190). Lublin: UP Lublin.

Sławiński, M. (2001). The boundary of the forest as a protected zone. Analysis of selected vegetation ecotones in Pomerania (in Polish). Sylwan, 145(2), 77-86.

Søndergaard, M., Johanosson, S., Lauridsen, T., Jørgensen, T. B., Liboriussen, L. \& Jeppesen E. (2010). Submerged macrophytes as indicators of the ecological quality of lakes. Freshw. Biol., 55, 893-908. DOI: 10.1111/j.13652427.2009.02331.x.

Starzyńska, W. (2005). Practical statistics (in Polish). Warszawa: Publ. PWN.

Szmeja, J. (2006). Guide to the study of aquatic vegetation (in Polish). Gdańsk: Wyd. UG.

Zarzycki, K. \& MirekZ. (2006) Red list of plants and fungi in Poland (in Polish). Kraków: Instytut Botaniki im. W. Szafera PAN. 